\title{
Recombinant Thyroglobulin
}

National Cancer Institute

\section{Source}

National Cancer Institute. Recombinant Thyroglobulin. NCI Thesaurus. Code C884.

A recombinant form of thyrog lobulin identical to or similar to the endogenous iodinecontaining glycoprotein. Thyroglobulin is synthesized in the thyroid follicular cell, and is the precursor of thyroid hormones T3 and T4. Thyrog lobulin levels can serve as a tumor marker for monitoring the status of differentiated thyroid carcinomas. 